\title{
In vaginal fluid, bacteria associated with bacterial vaginosis can be suppressed with lactic acid but not hydrogen peroxide
}

\author{
Deirdre E O'Hanlon ${ }^{1 *}$, Thomas R Moench ${ }^{2}$ and Richard A Cone ${ }^{1,2}$
}

\begin{abstract}
Background: Hydrogen peroxide $\left(\mathrm{H}_{2} \mathrm{O}_{2}\right)$ produced by vaginal lactobacilli is generally believed to protect against bacteria associated with bacterial vaginosis (BV), and strains of lactobacilli that can produce $\mathrm{H}_{2} \mathrm{O}_{2}$ are being developed as vaginal probiotics. However, evidence that led to this belief was based in part on non-physiological conditions, antioxidant-free aerobic conditions selected to maximize both production and microbicidal activity of $\mathrm{H}_{2} \mathrm{O}_{2}$. Here we used conditions more like those in vivo to compare the effects of physiologically plausible concentrations of $\mathrm{H}_{2} \mathrm{O}_{2}$ and lactic acid on a broad range of $\mathrm{BV}$-associated bacteria and vaginal lactobacilli.

Methods: Anaerobic cultures of seventeen species of BV-associated bacteria and four species of vaginal lactobacilli were exposed to $\mathrm{H}_{2} \mathrm{O}_{2}$, lactic acid, or acetic acid at pH 7.0 and pH 4.5. After two hours, the remaining viable bacteria were enumerated by growth on agar media plates. The effect of vaginal fluid (VF) on the microbicidal activities of $\mathrm{H}_{2} \mathrm{O}_{2}$ and lactic acid was also measured.

Results: Physiological concentrations of $\mathrm{H}_{2} \mathrm{O}_{2}(<100 \mu \mathrm{M})$ failed to inactivate any of the $\mathrm{BV}$-associated bacteria tested, even in the presence of human myeloperoxidase (MPO) that increases the microbicidal activity of $\mathrm{H}_{2} \mathrm{O}_{2}$. At $10 \mathrm{mM}, \mathrm{H}_{2} \mathrm{O}_{2}$ inactivated all four species of vaginal lactobacilli but only one of seventeen species of $\mathrm{BV}$-associated bacteria. Moreover, the addition of just 1\% vaginal fluid (VF) blocked the microbicidal activity of $1 \mathrm{M} \mathrm{H}_{2} \mathrm{O}_{2}$. In contrast, lactic acid at physiological concentrations (55-111 mM) and pH (4.5) inactivated all the BV-associated bacteria tested, and had no detectable effect on the vaginal lactobacilli. Also, the addition of $10 \% \mathrm{VF}$ did not block the microbicidal activity of lactic acid.

Conclusions: Under optimal, anaerobic growth conditions, physiological concentrations of lactic acid inactivated BV-associated bacteria without affecting vaginal lactobacilli, whereas physiological concentrations of $\mathrm{H}_{2} \mathrm{O}_{2}$ produced no detectable inactivation of either BV-associated bacteria or vaginal lactobacilli. Moreover, at very high concentrations, $\mathrm{H}_{2} \mathrm{O}_{2}$ was more toxic to vaginal lactobacilli than to BV-associated bacteria. On the basis of these in vitro observations, we conclude that lactic acid, not $\mathrm{H}_{2} \mathrm{O}_{2}$, is likely to suppress BV-associated bacteria in vivo.
\end{abstract}

\section{Background}

Bacterial vaginosis (BV) is a common, frequently recurrent condition in which a relatively sparse, lactobacillidominated vaginal microbial community is replaced by a dense mixture of Gram-variable and Gram-negative bacteria. Since hydrogen peroxide $\left(\mathrm{H}_{2} \mathrm{O}_{2}\right)$ is a broad-spectrum microbicidal disinfectant, the ability of some

\footnotetext{
* Correspondence: eohanlon@jhu.edu

'Mucosal Protection Laboratory, Thomas C Jenkins Department of Biophysics, Johns Hopkins University, 3400 North Charles Street, Baltimore MD 21218, USA

Full list of author information is available at the end of the article
}

strains of lactobacilli to produce $\mathrm{H}_{2} \mathrm{O}_{2}$ suggested that these strains might help prevent $\mathrm{BV}$. Women with $\mathrm{H}_{2} \mathrm{O}_{2}$-producing lactobacilli are less likely to have $\mathrm{BV}$ than are women without $\mathrm{H}_{2} \mathrm{O}_{2}$-producing lactobacilli [1-3]. Additionally, $\mathrm{H}_{2} \mathrm{O}_{2}$-producing lactobacilli were shown to inactivate several species of BV-associated bacteria under aerobic in vitro conditions and in the absence of the anti-oxidants present in physiological fluids $[4,5]$. Lactobacilli strains that produce $\mathrm{H}_{2} \mathrm{O}_{2}$ are now being selected for developing vaginal probiotics [6-8].

\section{Biomed Central}


However, recent work in our laboratory [9] has shown that under the hypoxic conditions that generally prevail in the vagina, $\mathrm{H}_{2} \mathrm{O}_{2}$ production by vaginal lactobacilli is undetectable (detection threshold $10 \mathrm{nM}$ ). Even with extended aerobic exposures in vitro, the mean $\mathrm{H}_{2} \mathrm{O}_{2}$ concentration achieved by lactobacilli in vaginal fluid (VF) was only $23 \mu \mathrm{M} \pm 5 \mu \mathrm{M}$, approximately 100 -fold lower than the concentration of $\mathrm{H}_{2} \mathrm{O}_{2}$ achieved by lactobacilli under aerobic in vitro conditions in the absence of anti-oxidants. Furthermore, VF has sufficient anti-oxidant activity to block the microbicidal activity of $\mathrm{H}_{2} \mathrm{O}_{2}$ even when $\mathrm{H}_{2} \mathrm{O}_{2}$ is supplied at concentrations much higher than lactobacilli are capable of producing. We believe these findings make protection by $\mathrm{H}_{2} \mathrm{O}_{2}$ implausible in vivo.

Vaginal lactobacilli produce several target-specific antimicrobial factors, including bacteriocins $[10,11]$, bacteriocins-like substances [12], and selective ligands [13]. However, given the broad spectrum of BV-associated bacteria and the diverse reproductive tract infections that occur more frequently in women with BV, we chose to compare the microbicidal activities of the most robust broad-spectrum antimicrobials that lactobacilli are known to produce: $\mathrm{H}_{2} \mathrm{O}_{2}$ and lactic acid. Hydrogen peroxide causes oxidative stress in bacterial cells [14], at least partially by oxidizing sulphydrals, and by oxidizing free iron to produce hydroxyl radicals that react with nucleic acids [15]. Lactic acid, under acidic conditions, can permeate cell membranes, acidify the cytosol $[16,17]$, and induce osmotic stress [18]. Lactic acid has also been shown to have broad spectrum activity against Gram-negative bacteria, probably by weakening the cell wall [19]. To clarify whether cytosolic acidification is the primary anti-microbial action of lactic acid, we also observed the effects of acetic acid, which is elevated during episodes of BV [20,21], and which, by being smaller and more lipid soluble, can acidify cytosol more rapidly than lactic acid [22].

The aim of this study, therefore, was to compare the antimicrobial actions of $\mathrm{H}_{2} \mathrm{O}_{2}$, lactic acid, and acetic acid on BV-associated bacteria and on vaginal lactobacilli under anaerobic growing conditions that approximate the hypoxic environment of the vagina [23]. We also examined the effects of VF, which consists of endocervical mucus that has entered the vagina and mixed with shed cells and transudated fluid from the vaginal epithelium. VF is acidified with lactic acid to $\leq \mathrm{pH} 4.5$ if the vaginal microbial community is dominated by lactobacilli [24]. We selected seventeen different species of bacteria that have been associated with BV by either bacteriological or molecular methods. We also studied four of the most common species of vaginal lactobacilli, including the recently identified Lactobacillus iners. We tested microbicidal activity at $\mathrm{pH} 4.5$ (the highest non- menstrual vaginal $\mathrm{pH}$ expected in the absence of BV) and $\mathrm{pH} 7.0$ (the approximate $\mathrm{pH}$ of the vagina during menses, and briefly following exposure to semen.

\section{Methods}

All materials and reagents were supplied by SigmaAldrich Inc., (St. Louis MO), unless otherwise specified; all microorganisms were supplied by the American Type Culture Collection (Manassas VA).

\section{Lactobacilli}

Lactobacillus crispatus ATCC 33820 was grown in ATCC medium 1490 (Modified chopped meat medium), L. jensenii ATCC 25258 and L. gasseri ATCC were grown in ATCC medium 416 (Lactobacilli MRS broth), L. iners ATCC 55195 was grown in ATCC medium 1685 (NYC III medium). Each species was grown anaerobically without agitation at $37^{\circ} \mathrm{C}$ for 24 hours before use in an experiment.

\section{Bacteria associated with bacterial vaginosis}

Gardnerella vaginalis ATCC 14018 was grown in ATCC medium 1685 (NYC III medium). Prevotella bivia ATCC 29303, Prevotella corporis ATCC 33547, Anaerococcus prevotii ATCC 14952, Fusobacterium nucleatum ATCC 25586 and Porphyromonas levii ATCC 29147 were all grown in ATCC medium 1490 (Modified chopped meat medium); Bacteroides ureolyticus ATCC 33387 was grown in ATCC medium 1490 with formate and fumarate. Peptostreptococcus anaerobius ATCC 27337, Anaerococcus tetradius ATCC 35098, Atopobium vaginae ATCC BAA-55, Megasphaera elsdenii ATCC 25940, and Propionibacterium acnes ATCC 6919 were all grown in ATCC medium 1053 (Reinforced Clostridial medium) supplemented with $5 \%$ defibrinated rabbit blood (Colorado Serum Company, Denver CO). Ureaplasma urealyticum ATCC 27618 was grown in ATCC medium 1331 (Urea broth); Mobiluncus curtisii ATCC 35241 and Mobiluncus mulieris ATCC 35239 were grown in BBL ${ }^{\mathrm{TM}}$ Schaedler medium (Becton, Dickinson and Company, Sparks MD). Mycoplasma hominis ATCC 23114 was grown in ATCC medium 243 (Mycoplasma medium). Micromonas micros ATCC 33270 was grown in ATCC medium 1102 (Chopped meat medium) supplemented with $0.1 \%$ each of cellobiose, maltose, starch, and Tween 80. Each species was grown anaerobically in a $50 \mathrm{~mL}$ volume of its recommended growth medium without agitation at $37^{\circ} \mathrm{C}$ for 24 or 48 hours before use in an experiment, yielding bacterial concentrations between approximately $10^{6}$ and $10^{9}$ colonyforming units (cfu) per $\mathrm{mL}$ (48 hour incubations were used for bacteria that failed to produce consistently = $10^{6} \mathrm{cfu} / \mathrm{mL}$ after 24 hour incubations). The relatively high concentrations of bacteria used were chosen both 
to increase the dynamic range of the experiments (i.e., large numbers of bacteria permit a more meaningful quantification of observed inactivation), and to reflect the high density of bacteria seen in vivo [25].

\section{Microbicidal activity}

Experimental media for each organism were prepared by adding $\mathrm{H}_{2} \mathrm{O}_{2}$, lactic acid, or acetic acid to the appropriate growth medium for that organism; they were not added to control media. For experiments using $\mathrm{H}_{2} \mathrm{O}_{2}$, both experimental and control media contained $50 \mathrm{mU} /$ $\mathrm{mL}$ human myeloperoxidase (MPO). All growth medium formulations contained at least ten-times more than the $1 \mathrm{mM}$ concentration of chloride ions required for full activity of a myeloperoxidase-halide- $\mathrm{H}_{2} \mathrm{O}_{2}$ microbicidal system [26]. Aliquots of each experimental and control medium were titrated with sodium hydroxide or hydrochloric acid as necessary to obtain a $\mathrm{pH}$ of either 4.5 or 7.0 (with allowance made for the change in $\mathrm{pH}$ that would occur when an aliquot of bacterial culture was added, as described below).

Bacterial cultures were gently agitated immediately before use. A $100 \mu \mathrm{L}$ aliquot of culture was added to 9.9 $\mathrm{mL}$ of each control or experimental medium; media and bacteria were then incubated anaerobically at $37^{\circ} \mathrm{C}$. Two replicate samples were removed from control and experimental conditions after ten minutes, thirty minutes, one hour, and two hours exposure. Each sample was then serially diluted with the appropriate growth medium containing $200 \mathrm{mM}$ HEPES ( $\mathrm{pH}$ 6.8-7.2 depending on growth medium) and track-plated [27] onto the appropriate growth medium containing 1.5\% (w/v) ultrapure agar (USB Corporation, Cleveland $\mathrm{OH}$ ). The $\mathrm{pH}$ of each experimental or control medium was re-measured after the experiment to confirm it had remained within $0.1 \mathrm{pH}$ units of the starting $\mathrm{pH}$. Agar plates were incubated anaerobically at $37^{\circ} \mathrm{C}$ for 24 or 48 hours, until colonies could be easily distinguished and counted. Colonies on some plates were recounted after a further 48 hours incubation to allow for extended lagphases in treated cells; however, no further changes in colony-counts were observed. Each experiment was independently repeated at least four times.

\section{Bacterially-depleted vaginal fluid Participants}

The study was carried out at the Johns Hopkins University Homewood campus. Each participant gave written informed consent under a protocol approved by the Homewood Institutional Review Board on the Use of Human Subjects at Johns Hopkins University. Participants were required to be between 18 and 45 years old, in good general health, at least three days past the most recent menstruation or unprotected penile-vaginal intercourse, at least three weeks past the most recent use of vaginal or systemic antimicrobials, and free from vaginal symptoms (discharge, odor, itching, or pain). Results from twenty-two samples donated by eight participants are reported here; the group comprised roughly equal numbers of non-Hispanic whites, blacks, and Asians, aged between 21 and 44 years old (mean age 27 \pm 4 years)

\section{Collection of vaginal fluid samples}

For these experiments, undiluted non-menstrual VF was collected at the laboratory using the non-absorbent disposable Instead ${ }^{\circledR}$ Softcup ${ }^{\mathrm{TM}}$ menstrual device (Evofem Inc., San Diego CA) [28]. The Softcup was vaginally inserted, removed, and placed in a conical centrifuge tube. The collected VF was removed from the Softcup by centrifugation for one minute at $500 \mathrm{~g}$; the Softcup was then discarded.

A sterile cotton swab was dipped into the collected fluid, rolled out onto a glass microscope slide, and airdried for later Gram-staining and Nugent-scoring. A total of eight participants donated VF; all samples had Nugent score $\leq 3$ and no evidence of leukorrhea (the mean PMNL/hpf of the samples was 2.3). As reported earlier, VF samples as obtained contain 1\% lactic acid and $\sim 20 \mu \mathrm{M} \mathrm{H}_{2} \mathrm{O}_{2}$ [9,29].

To avoid conflating endogenous vaginal bacteria with the cultured bacteria used in these experiments, bacterially-depleted VF was prepared: each collected sample was diluted with a half-volume of sterile saline $(0.9 \%$ [w/v] sodium chloride), mixed thoroughly, centrifuged at $1000 \mathrm{~g}$ for three minutes, and the supernatant was drawn off for immediate use in an experiment. Pilot experiments showed that this centrifugation reduced bacterial concentrations in the diluted VF by a factor of approximately $10^{6}$, from a pre-centrifugation mean of $5.6 \times 10^{7} \mathrm{cfu} / \mathrm{mL}$ to a post centrifugation mean of $4.0 \times$ $10^{1} \mathrm{cfu} / \mathrm{mL}$ (data not shown). Rather than pooling VF samples for use in experiments, individual samples from at least four different participants were used in conjunction with each treatment $\left(\mathrm{H}_{2} \mathrm{O}_{2}\right.$ or lactic acid) to assess the reproducibility of results across different VF samples.

The effect of VF on the microbicidal activities of $\mathrm{H}_{2} \mathrm{O}_{2}$ and lactic acid against seven prevalent species of $\mathrm{BV}$ associated bacteria (G. vaginalis, A. vaginae, $P$. bivia, $P$. anaerobius, M. curtisii, M. mulieris, and M. hominis) and four species of vaginal lactobacilli was measured. Each organism was exposed to growth medium containing an inactivating concentration of $\mathrm{H}_{2} \mathrm{O}_{2}(3.4 \% \mathrm{w} / \mathrm{v}$ [1 $\mathrm{M}$ ] with $50 \mathrm{mU} / \mathrm{mL} \mathrm{MPO}$ at $\mathrm{pH} 7)$ or lactic acid $(1 \% \mathrm{w} /$ $\mathrm{v}$ [111 $\mathrm{mM}]$ at $\mathrm{pH} 4.5$ ), with or without the addition of bacterially depleted VF to a final VF concentration of $1 \%$ or $10 \%(\mathrm{v} / \mathrm{v})$. In all cases, the bacterially depleted VF was added to the experimental media and mixed for five 
seconds before the addition of bacteria. The $\mathrm{pH}$ of the experimental media was also checked before the addition of bacteria, and if necessary readjusted to 4.5 or 7.0. Samples were removed from control and experimental conditions after ten minutes, thirty minutes, one hour, and two hours, serially diluted, plated and enumerated as described above.

\section{Statistical analysis}

Results are reported as means of at least six independently repeated experiments (two replicates performed within each experiment). The difference between three or more means was tested using an ANOVA one-way analysis of variance; difference between two means was tested using a two-tailed Student's $t$ test (comparisons are paired unless otherwise indicated in the results); $p$ values $\leq 0.05$ were considered to be statistically significant. Statistical analysis was performed using PHStat2 version 3.0 (Microsoft Excel add-on). Due to the large amount of data presented in the graphs, standard deviations have been omitted for visual clarity; however, there were no significant differences among data from different replicates or repeats of individual experiments (differences were less than a $\log _{10}$ unit in all cases).

\section{Results}

The results presented here report the effects of a twohour exposure to $\mathrm{H}_{2} \mathrm{O}_{2}$, lactic acid, or acetic acid, with or without the addition of VF. Data collected at shorter exposures differed only in the proportion of each bacteria inactivated, not in the relative efficacy of the antimicrobial agents, or in the effect of VF on bacterial inactivation.

\section{Microbicidal activity of hydrogen peroxide}

A two-hour anaerobic exposure to $100 \mathrm{mM} \mathrm{H}_{2} \mathrm{O}_{2}$ with $50 \mathrm{mU} / \mathrm{mL}$ MPO at $\mathrm{pH} 7$ reduced the viability of all four vaginal lactobacilli species and all seventeen BVassociated bacterial species to undetectable levels (a measured reduction of between $10^{6}$ and $10^{9}$ organisms per $\mathrm{mL}$, depending on the initial bacterial concentration). This demonstrates the broad-spectrum activity of $\mathrm{H}_{2} \mathrm{O}_{2}$ (Figure 1). However, this concentration is approximately 50-fold higher than lactobacilli are capable of producing even under optimal aerobic, low-antioxidant conditions, and approximately 5,000-fold higher than the estimated $\mathrm{H}_{2} \mathrm{O}_{2}$ concentration in vivo (VF). The microbicidal activity of $\mathrm{H}_{2} \mathrm{O}_{2}$ was not enhanced by lower $\mathrm{pH}$; indeed, at $\mathrm{pH} 4.5 \mathrm{H}_{2} \mathrm{O}_{2}$ with $\mathrm{MPO}$ produced less reduction in viability than at $\mathrm{pH} 7$, presumably due to reduced activity of MPO at the lower $\mathrm{pH}$ (data not shown). The addition of just $1 \%$ bacterially depleted VF completely blocked the microbicidal activity of $1 \mathrm{M}$ $\mathrm{H}_{2} \mathrm{O}_{2}$ with $50 \mathrm{mU} / \mathrm{mL}$ myeloperoxidase at $\mathrm{pH}$ 7; no significant inactivation was detected in any of the eleven

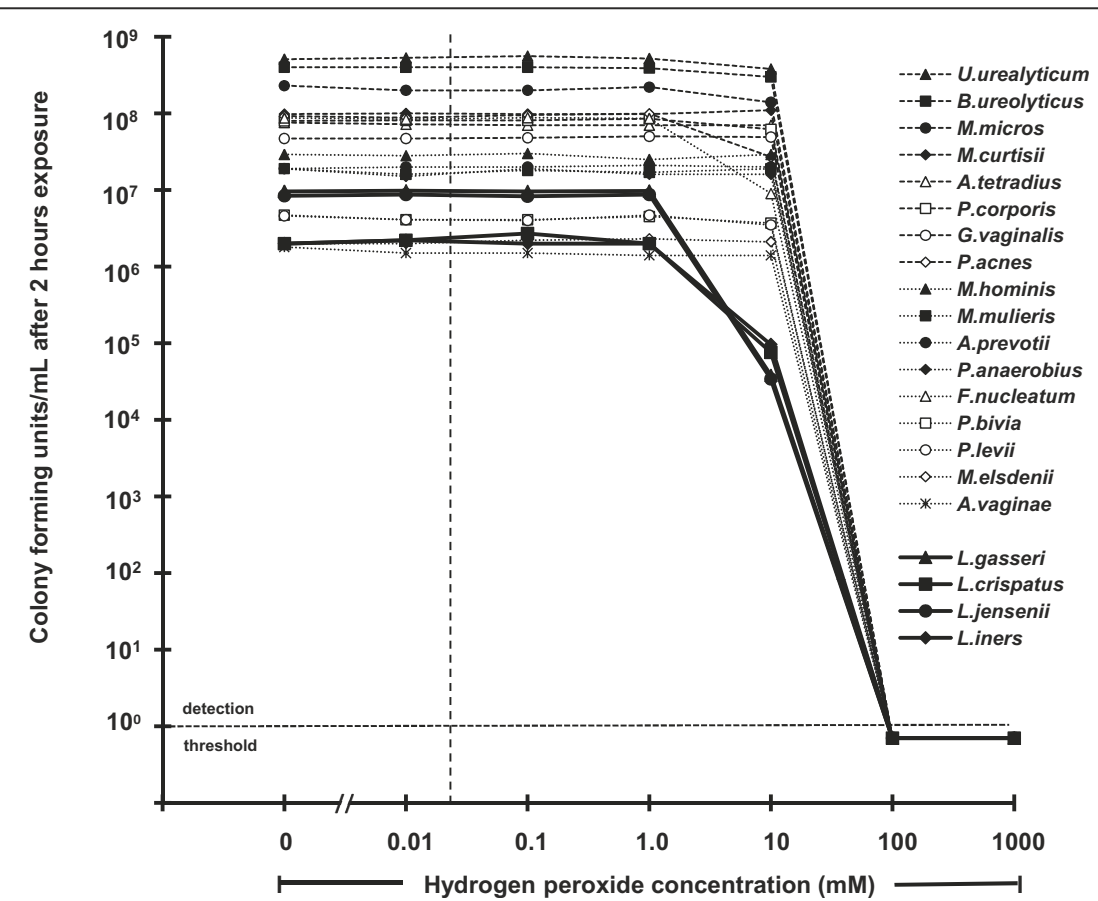

Figure 1 Microbicidal activity of hydrogen peroxide $\left(\mathrm{H}_{2} \mathrm{O}_{2}\right)$ with $50 \mathrm{mU} / \mathrm{mL}$ human myeloperoxidase (MPO) at pH 7, against four species of vaginal lactobacilli (solid lines) and seventeen species of bacteria associated with bacterial vaginosis (BV) (broken lines). The vertical dashed line indicates the concentration of $\mathrm{H}_{2} \mathrm{O}_{2}$ measured in vaginal fluid (VF) from women with a lactobacilli-dominated microbiota $(\sim 23 \mu \mathrm{M})$. 
bacterial species tested (Figure 2). It is worth emphasizing that we tested the effect of $1 \mathrm{M} \mathrm{H}_{2} \mathrm{O}_{2}$ to determine the potency of VF for blocking the microbicidal activity of $\mathrm{H}_{2} \mathrm{O}_{2}$, but this concentration is higher than is physiologically plausible.

Microbicidal activity of acidity, lactic acid, and acetic acid Acidity alone ( $\mathrm{pH} 4.5$ compared to $\mathrm{pH} 7)$ reduced the viability of all seventeen BV-associated bacteria (a reduction of between two-fold and $10^{4}$-fold, depending on bacterial species) after two hours exposure, but had no effect on any of the four lactobacilli species tested ("0, $\mathrm{pH} 7$ ", and " $0, \mathrm{pH} 4.5$ " data points in Figure 3). Similarly, acetic acid caused essentially no additional inactivation compared to $\mathrm{pH} 4.5$ alone except at $0.8 \mathrm{M}$ (5\% $\mathrm{w} / \mathrm{v})$, where it caused only partial additional inactivation (Figure 4).

In striking contrast, the addition of lactic acid greatly increased the microbicidal potency at $\mathrm{pH} 4.5: 0.5 \% \mathrm{w} / \mathrm{v}$ $(56 \mathrm{mM})$ lactic acid, a concentration and acidity at the lower end of the range observed in a healthy vaginal environment [29], dramatically reduced the viability of all BV-associated species, with all but one (M. mulieris) reduced to undetectable levels (a measured reduction of $10^{6}$-fold to $10^{8}$-fold depending on the initial bacterial concentration). Not surprisingly given that they produce lactic acid, all four lactobacilli species tested were unaffected by lactic acid at a concentration of $0.5 \% \mathrm{w} / \mathrm{v}$ $(56 \mathrm{mM})$; indeed, the lactobacilli were unaffected by $10 \% \mathrm{w} / \mathrm{v}(1110 \mathrm{mM})$ lactic acid, an order of magnitude more lactic acid than we measured in VF from women with a lactobacilli-dominated vaginal microbiota [[29], and manuscript in preparation]. Moreover, addition of $1 \%$ or $10 \% \mathrm{v} / \mathrm{v}$ bacterially-depleted VF did not change the microbicidal effect of $56 \mathrm{mM}$ lactic acid at $\mathrm{pH} 4.5$; all BV-associated bacteria tested were completely inactivated, and lactobacilli were unaffected (Figure 5). The microbicidal activity of lactic acid required low pH; at pH 7.0 lactic acid did not inactivate any of the bacteria tested (data not shown).

\section{Discussion}

Here we report that physiologically plausible concentrations of $\mathrm{H}_{2} \mathrm{O}_{2}$ had no microbicidal activity, while a supraphysiologic concentration of exogenous $\mathrm{H}_{2} \mathrm{O}_{\mathrm{s}}$ $(0.34 \% \mathrm{w} / \mathrm{v}, 100 \mathrm{mM})$ just high enough to inactivate BVassociated bacteria more potently inactivated vaginal lactobacilli. In contrast, physiological concentrations of lactic acid $(0.5 \% \mathrm{w} / \mathrm{v}, 56 \mathrm{mM})$ at $\mathrm{pH} 4.5$ completely inactivated sixteen of the seventeen species of BV-associated bacteria tested; $\mathrm{pH} 4.5$ is the highest $\mathrm{pH}$ likely to occur when lactobacilli dominate the vaginal bacterial community [[25], and manuscript in preparation]. The differential effect observed was opposite to that expected

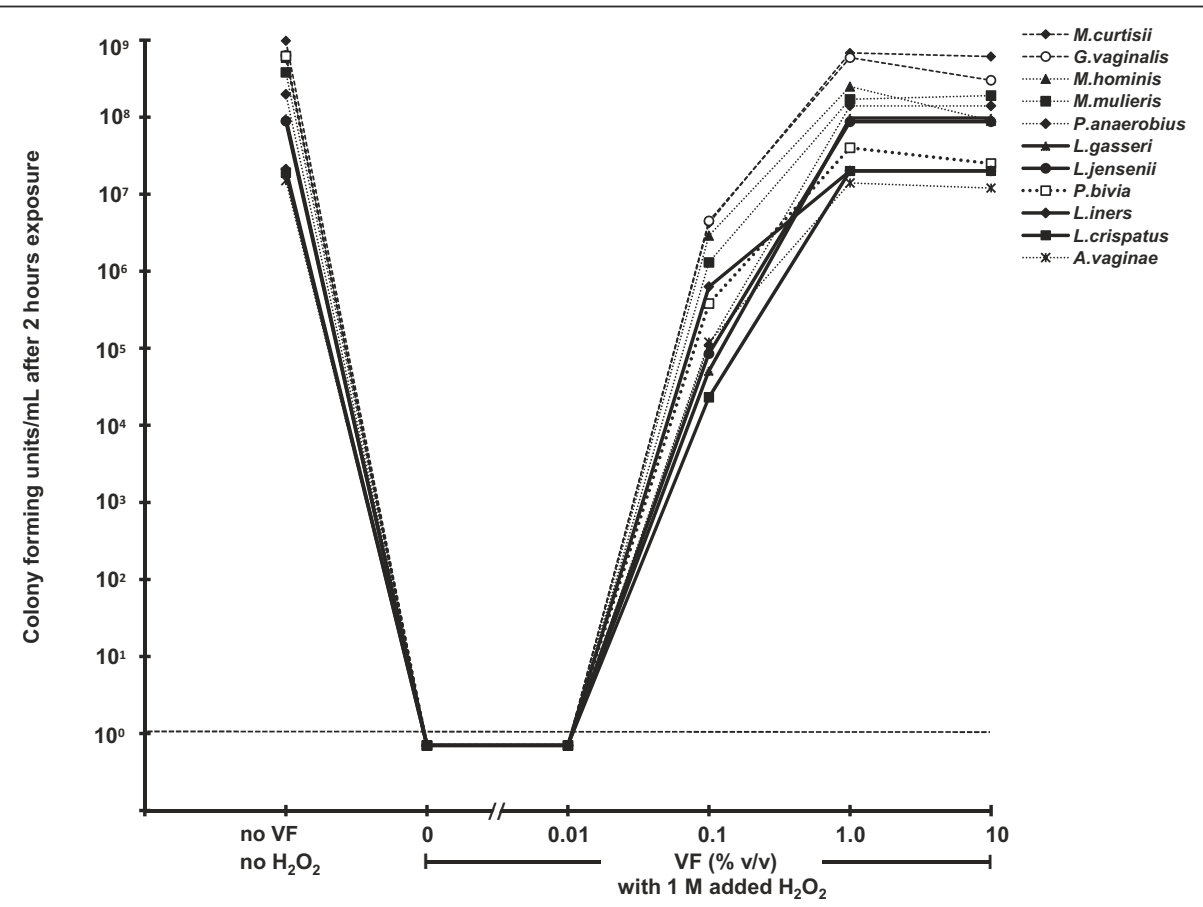

Figure 2 The blocking effect of bacterially-depleted VF on the microbicidal activity of $1 \mathrm{M} \mathrm{H}_{2} \mathrm{O}_{2}$ with $50 \mathrm{mU} / \mathrm{mL} \mathrm{MPO}$, which is otherwise sufficient to inactivate completely four species of lactobacilli (solid lines) and seven species of BV-associated bacteria (broken lines). 


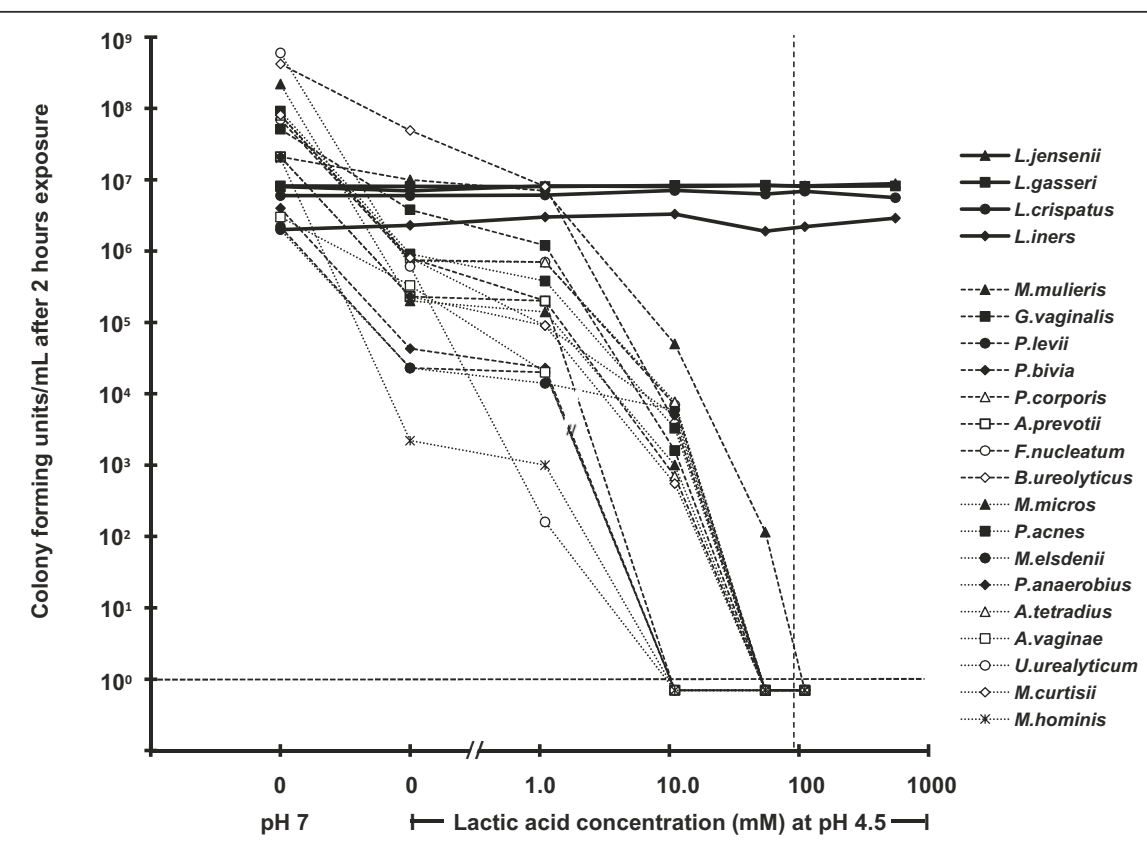

Figure 3 Microbicidal activity of lactic acid at pH 4.5 against four species of vaginal lactobacilli (solid lines) and seventeen species of BV-associated bacteria (broken lines). The vertical dashed line indicates the mean concentration of lactic acid measured in VF from women with a lactobacilli-dominated vaginal microbiota $(93 \mathrm{mM})$.

if lactobacilli suppress BV-associated bacteria with $\mathrm{H}_{2} \mathrm{O}_{2}$. This also argues against the possibility that $\mathrm{H}_{2} \mathrm{O}_{2}$ might be protective at high local concentrations. Additionally, as we have previously reported, addition of only $1 \%$ VF blocks the microbicidal activity of $\mathrm{H}_{2} \mathrm{O}_{2}$ - producing strains of lactobacilli even in an optimized, aerobic, low-antioxidant buffer system [4].

At low $\mathrm{pH}$, small weak acids like acetic acid and lactic acid become uncharged free acids that are lipid soluble, membrane permeant, and capable of acidifying the

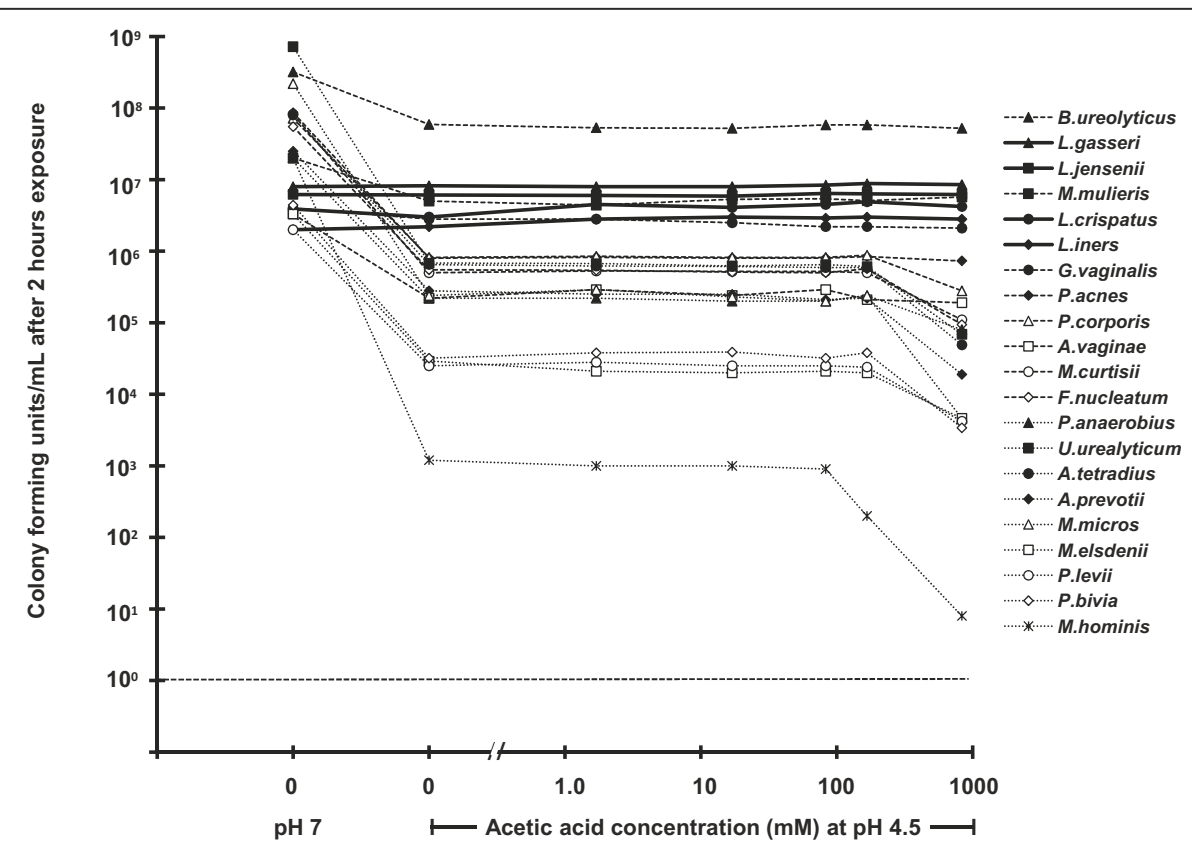

Figure 4 Microbicidal activity of acetic acid at pH 4.5 against four species of vaginal lactobacilli (solid lines) and seventeen species of BV-associated bacteria (broken lines). 


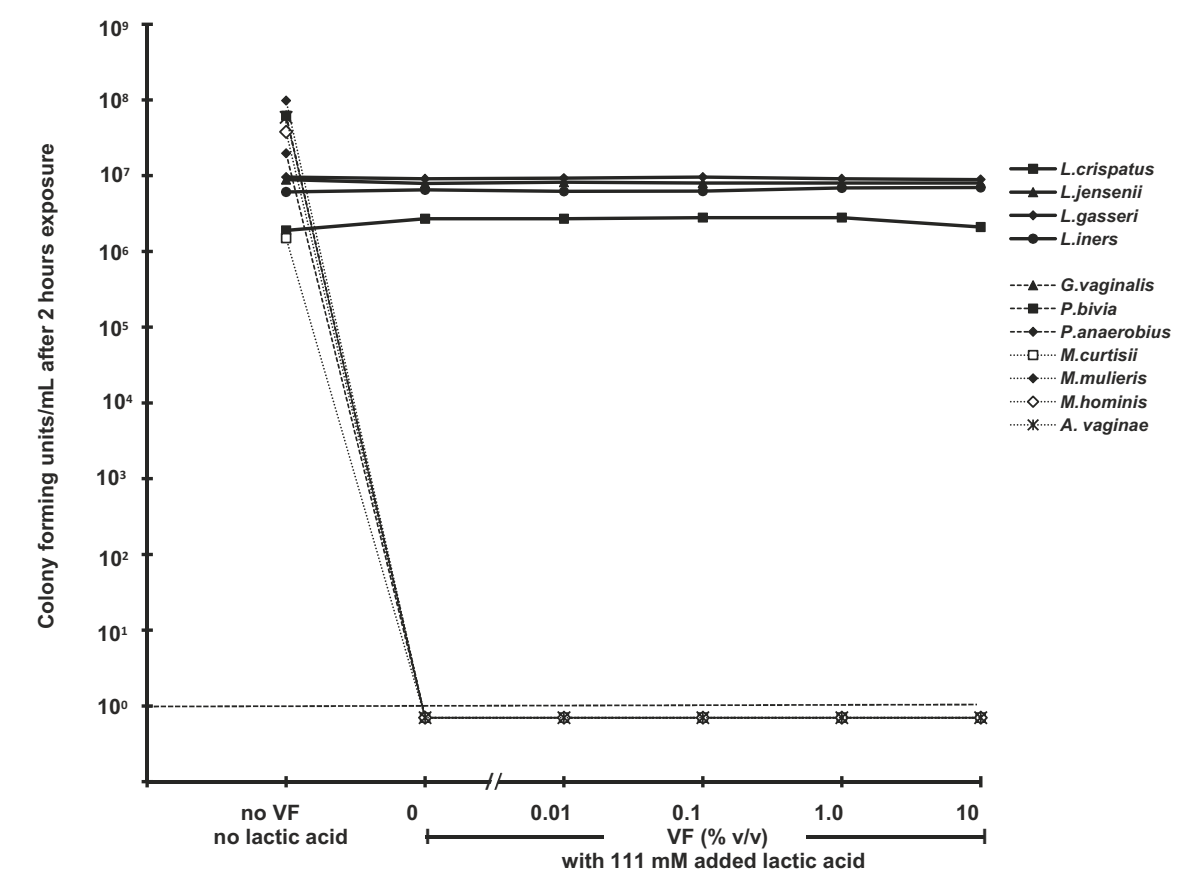

Figure 5 The effect of bacterially-depleted VF on the microbicidal activity of $100 \mathrm{mM}$ lactic acid at pH 4.5, which is otherwise sufficient to inactivate completely seven species of BV-associated bacteria (broken lines), but not four species of lactobacilli (solid lines).

cytosol. The $\mathrm{p} K_{a}$ for acetic acid is $\sim 4.8$, thus when vaginal $\mathrm{pH}$ is $<4$, acetic acid exists primarily as the uncharged free acid. In contrast, the $\mathrm{p} K a$ for lactic acid is $\sim 3.8$ and thus at vaginal $\mathrm{pH}$ much of it is the far less membrane permeant lactate anion. Acetic acid is both smaller and more lipid soluble than lactic acid and hence acetic acid is expected to acidify the cytosol more rapidly than lactic acid and be more rapidly bactericidal than lactic acid. Despite this expectation, we found that acetic acid had no detectable effects until its concentration was increased to $5 \%$ (household vinegar). Therefore, the marked inhibition of BV-associated bacteria by lactic acid clearly indicates that the antimicrobial action of lactic acid is not based simply on cytosolic acidification. Instead, as suggested by other studies, lactic acid appears to have specific effects, for example, disturbing the cell membranes of Gram-negative bacteria [22].

Menstrual fluid neutralizes the vagina, and we found that at $\mathrm{pH} 7$ lactic acid had no microbicidal activity against $\mathrm{BV}$-associated bacteria. This result is consistent with the clinical observation of $\mathrm{BV}$ recurrence after menses [30,31].

Our observations carry the caveat of all in vitro observations, namely that the activities of $\mathrm{H}_{2} \mathrm{O}_{2}$, lactic acid, and acetic acid in vitro may not be the same as in vivo.

Additionally, inactivation of lactobacilli during a transient anaerobic exposure to exogenous $\mathrm{H}_{2} \mathrm{O}_{2}$ may not reveal tolerance mechanisms that might occur in aerobic conditions when lactobacilli can produce $\mathrm{H}_{2} \mathrm{O}_{2}$. However, lactobacilli inactivate themselves by endogenous $\mathrm{H}_{2} \mathrm{O}_{2}$ production [32,33], indicating that they do not possess adequate mechanisms to overcome $\mathrm{H}_{2} \mathrm{O}_{2}$ toxicity. Lactobacilli and $\mathrm{BV}$-associated bacteria were used at relatively high concentrations for these experiments; however, the concentrations used here reflect those found in vivo. Finally, we investigated single species in vitro, not combinations, and there may be synergistic effects of combinations of BV-associated bacteria that might significantly alter the results in vivo.

\section{Conclusions}

We found that addition of hydrogen peroxide was not microbicidal at physiologically plausible concentrations. When supplied at microbicidal concentrations, $\mathrm{H}_{2} \mathrm{O}_{2}$ inactivated vaginal lactobacilli somewhat more potently than BV-associated bacteria. Conversely, addition of lactic acid at physiological concentrations was microbicidal against BV-associated bacteria, but had no effect on vaginal lactobacilli. Additionally, the presence of VF blocked the microbicidal activity of $\mathrm{H}_{2} \mathrm{O}_{2}$ but not of lactic acid. We conclude that $\mathrm{H}_{2} \mathrm{O}_{2}$ production by lactobacilli is an implausible mechanism for suppressing BVassociated bacteria in vivo, and that lactic acid production at rates that acidify the vagina may potently suppress BV-associated bacteria. 


\section{Acknowledgements}

The work was supported by NIH grants Al45967, Al60598, and Al66726.

\section{Author details}

'Mucosal Protection Laboratory, Thomas C Jenkins Department of Biophysics, Johns Hopkins University, 3400 North Charles Street, Baltimore MD 21218, USA. ${ }^{2}$ ReProtect Inc., 703 Stags Head Road, Baltimore MD 21704 USA.

\section{Authors' contributions}

DEOH designed the study, collected the data, analyzed the data, and prepared the manuscript. TM and RC participated in data analysis and the preparation of the manuscript. All of the authors read and approved the final manuscript.

\section{Competing interests}

Based on the results reported in this paper, the authors have applied for patents on devices and methods for sustained release of lactic acid, with assignment to ReProtect and Johns Hopkins University. TRM and RAC own equity in ReProtect.

\section{Received: 3 February 2011 Accepted: 19 July 2011}

Published: 19 July 2011

\section{References}

1. Eschenbach DA, Davick PR, Williams BL, Klebanoff SJ, Young-Smith K, Critchlow CM, Holmes KK: Prevalence of hydrogen peroxide-producing Lactobacillus species in normal women and women with bacterial vaginosis. J Clin Microbiol 1989, 27:251-256.

2. Al-Mushrif $\mathrm{S}$, Jones $\mathrm{BM}$ : A study of the prevalence of hydrogen peroxide generating Lactobacilli in bacterial vaginosis: the determination of $\mathrm{H}_{2} \mathrm{O}_{2}$ concentrations generated in vitro by isolated strains and the levels found in vaginal secretions of women with and without infection. $J$ Obstet Gynaecol 1998, 18:63-67.

3. Cherpes TL, Hillier SL, Meyn LA, Busch JL, Krohn MA: A delicate balance: risk factors for acquisition of bacterial vaginosis include sexual activity, absence of hydrogen peroxide-producing lactobacilli, black race, and positive Herpes Simplex Virus Type 2 serology. Sex Trans Dis 2008, 35:78-83.

4. Klebanoff SJ, Hillier SL, Eschenbach DA, Waltersdorph AM: Control of the microbial flora of the vagina by $\mathrm{H}_{2} \mathrm{O}_{2}$-generating lactobacilli. JID 1991, 164:94-100.

5. Atassi F, Brassart $D, G r o b P$, Servin AL: Lactobacillus strains isolated from the vagina of healthy women inhibit Prevotella bivia and Gardnerella vaginalis in coculture and cell culture. FEMS Immunol Med Microbiol 2006, 48:424-432.

6. Falagas ME, Betsi Gl, Athanasiou S: Probiotics for treatment of women with bacterial vaginosis. Clin Microbiol Infect 2007, 13:657-664.

7. Xu HY, Tian WH, Wan CX, Jla LJ, Wang LY, Yuan J, Liu CM, Zeng M, Wei H: Antagonistic potential against pathogenic microorganisms and hydrogen production of indigenous lactobacilli isolated from the vagina of Chinese pregnant women. Biomed Environ Sci 2008, 21:365-371.

8. Martín R, Soberón N, Vaneechoutte M, Flórez AB, Vázquez F, Suárez JE: Characterization of indigenous vaginal lactobacilli from healthy women as probiotic candidates. Int Microbiol 2008, 11:261-266.

9. O'Hanlon DE, Lanier BR, Moench TR, Cone RA: Cervicovaginal fluid and semen block the microbicidal activity of hydrogen peroxide produced by vaginal lactobacilli. BMC Infect Dis 2010, 10:120.

10. Alpay-Karaoğlu S, Aydin F, Kiliç SS, Kiliç AO: Antimicrobial activity and characteristics of bacteriocins produced by vaginal lactobacilli. Turk $J$ Med Sci 2002, 33:7-12.

11. Aroutcheva A, Gariti D, Simon M, Shott S, Faro J, Simoes JA, Gurguis A, Faro S: Defense factors of vaginal lactobacilli. Am J Obstet Gynecol 2001, 185:375-9.

12. Ocaña VS, Pesce de Ruiz Holgado AA, Nader-Marcías ME: Characteristics of a bacteriocins-like substance produced by a vaginal Lactobacillus salivarius strain. Appl Env Microbiol 1991, 65:5631-5.

13. Boris $\mathrm{S}$, Barbés $\mathrm{C}$ : Role played by lactobacilli in controlling the population of vaginal pathogens. Microb Infect 2000, 2:543-6.

14. Imlay JA: Pathways of oxidative damage. Annu Rev Microbiol 2003, 57:395-418.
15. Imlay JA: How oxygen damages microbes: oxygen tolerance and obligate anaerobiosis. Adv Microb Physiol 2002, 46:111-53.

16. Kashket ER: Bioenergetics of lactic acid bacteria: cytoplasmic $\mathrm{pH}$ and osmotolerence. FEMS Microbiol Rev 1987, 46:233-44.

17. Russell JB, Diez-Gonzalez F: The effects of fermentation acids on bacterial growth. Adv Microb Physiol 1998, 39:205-34.

18. Diez-Gonzalez F, Russell JB: The ability Escherichia coli 0157:H7 to decease its intracellular $\mathrm{pH}$ and resist the toxicity of acetic acid. Microbiology 1997. 143:1175-80

19. Alakomi HL, Skyttä E, Saarela M, Mattila-Sandholm T, Latva-Kala K, Helander IM: Lactic acid permeabilizes gram-negative bacteria by disrupting the outer membrane. App Environ Microbiol 2000, 66:2001-5.

20. Stanek R, Gain RE, Glover DD, Larsen B: High performance ion exclusion chromatographic characterization of the vaginal organic acids in women with bacterial vaginosis. Biomed Chromatogr 1992, 6:231-5.

21. Chaudry AN, Travers PJ, Yuenger J, Colletta L, Evans P, Zenilman JM, Tummon A: Analysis of vaginal acetic acid in patients undergoing treatment for bacterial vaginosis. J Clin Microbiol 2004, 42:5170-5.

22. Shedlovsky L, Belcher D, Levenstein I: Titrations of human seminal fluid with acids and alkalis and their effects on the survival of sperm motility. Am J Physiol 1942, 136:535-541.

23. Sommer F, Caspers HP, Esders K, Klotz T, Engelman U: Measurement of vaginal and minor labial oxygen tension for the evaluation of female sexual function. J Urol 2001, 166:2324-5.

24. Boskey ER, Telsch KM, Whaley KJ, Moench TR, Cone RA: Acid production by vaginal flora in vitro is consistent with the rate and extent of vaginal acidification. Infect Immun 1999, 10:5170-5.

25. Masfari AN, Duerden Bl, Kinghorn GR: Quantitative studies of vaginal bacteria. Genitourin Med 1986, 62:256-63.

26. Klebanoff SJ: Myeloperoxidase-halide-hydrogen peroxide antibacterial system. J Bacteriol 1968, 95:2131-2138.

27. Jett BD, Hatter KL, Huycke MM, Gilmore M: Simplified agar plate method for quantifying viable bacteria. BioTechniques 1997, 23:648-650

28. Boskey ER, Moench TR, Hees PS, Cone RA: A self-sampling method to obtain large volumes of undiluted cervicovaginal fluids. Sex Trans Dis 2003, 30:107-109.

29. O'Hanlon DE, Moench TR, Harrold S, Cone RA: Microbicide production by vaginal lactobacilli: vaginal acidity $(\mathrm{pH})$ and lactic acid or more potent than previously reported. Poster presentation. Microbicides New Delhi 2008, Feb 24-28 2008.

30. Morison L, Ekpo G, West B, Demba E, Mayaud P, Coleman R, Bailey R, Walraven $G$ : Bacterial vaginosis in relation to menstrual cycle, menstrual protection method, and sexual intercourse in rural Gambian women. Sex Transm Infect 2005, 81:242-247.

31. Brotman RM, Ravel J, Cone RA, Zenilman JM: Rapid fluctuation of the vaginal microbiota measured by Gram stain analysis. Sex Transm Infect 2010, 86:297-302.

32. Ocaña VS, Pesce de Ruiz Holgado AA, Nader-Macías ME: Selection of vaginal $\mathrm{H}_{2} \mathrm{O}_{2}$-generating Lactobacillus species for probiotic use. Curr Microbiol 1999, 38:279-84

33. Hosoi T, Ametani A, Kiuchi K, Kaminogawa S: Improved growth and viability of lactobacilli in the presence of Bacillus subtilis (natto), catalase, or subtilisin. Can J Microbiol 2000, 46:892-7.

\section{Pre-publication history}

The pre-publication history for this paper can be accessed here: http://www.biomedcentral.com/1471-2334/11/200/prepub

\section{doi:10.1186/1471-2334-11-200}

Cite this article as: O'Hanlon et al:: In vaginal fluid, bacteria associated with bacterial vaginosis can be suppressed with lactic acid but not hydrogen peroxide. BMC Infectious Diseases 2011 11:200 